\title{
Professional Curriculum Practice of Economic and Management Sciences Teachers: A Case of Financial Literacy Teaching
}

\author{
Mojakgomo Moloi ${ }^{1, *}$, Habasisa Molise ${ }^{2}$ \\ ${ }^{1}$ Department of Economic and Management Sciences, Koos Mota Intermediate School, Free State, South Africa \\ ${ }^{2}$ Department of Human Science, School of Education, Sol Plaatje University, Kimberly, South Africa
}

Received February 18, 2021; Revised April 8, 2021; Accepted April 26, 2021

\section{Cite This Paper in the following Citation Styles}

(a): [1] Mojakgomo Moloi, Habasisa Molise , "Professional Curriculum Practice of Economic and Management Sciences Teachers: A Case of Financial Literacy Teaching," Universal Journal of Educational Research, Vol. 9, No. 5, pp. 1104-1112, 2021. DOI: 10.13189/ujer.2021.090524.

(b): Mojakgomo Moloi, Habasisa Molise (2021). Professional Curriculum Practice of Economic and Management Sciences Teachers: A Case of Financial Literacy Teaching. Universal Journal of Educational Research, 9(5), 1104-1112. DOI: 10.13189/ujer.2021.090524.

Copyright@2021 by authors, all rights reserved. Authors agree that this article remains permanently open access under the terms of the Creative Commons Attribution License 4.0 International License

\begin{abstract}
This paper investigates the professional curriculum practice of economic and management sciences (EMS) teachers in teaching financial literacy. Financial literacy is the accounting part of EMS. Studies confirm that EMS, as a subject, especially the financial literacy part, deals with the logical, systematic, and accurate selection and recording of financial information and transactions, as well as the compilation, analysis, interpretation, and communication of financial statements and managerial reports for use by interested parties. The study was qualitative, with three participants selected from one rural school in the Thabo Mofutsanyane education district. In-depth interviews were used to gather information regarding the professional curriculum practice of EMS teachers and how they teach financial literacy. The data were then analyzed using the lens proposed by Laws, Harper, and Marcus (2003), which involves identifying various themes that respond to the research questions. The study revealed that there were inadequate accounting cash journal subject content knowledge, and ineffective collaboration during financial literacy lessons. The findings suggest that there should be frequent lesson observations conducted to assist EMS teachers to teach financial literacy. However, concerted efforts should be made by heads of departments and subject advisors to capacitate teachers through sharing of instructional resources, and creating space for team
\end{abstract}

teaching/collaboration among teachers at the school and beyond.

Keywords Professional Curriculum Practice, Teaching and Learning, Financial Literacy, Accounting Teaching

\section{Introduction}

The professional curriculum practice (PCP) of economic and management sciences (EMS) was introduced into the South African curriculum in 1998, after education reform that was aimed at eradicating inequalities of the past [1]. Unfortunately, teachers are unable to meet the high expectations of the reform process as envisaged by the new curriculum, because MS) as a subject requires that teachers teach accounting cash journal calculations subject content knowledge collaboratively [2], which is not happening. This requirement poses an enormous challenge, because teachers are used to work as individuals. Adverse attitudes of teachers are a problem, not only in South Africa, but in the whole southern African sub-region. Kitta [3] reports that collaboration and team teaching are also major obstacles in Tanzania. The authors argue that collaboration is not integrated into school curriculum planning, and 
teachers are left to battle with curriculum implementation in their lessons on their own.

Although South Africa's Curriculum Assessment Policy Statement (CAPS) emphasizes proper planning [4], some EMS teachers adhere only partly to this practice, citing a heavy administrative load as a hindering factor [5]. Evidence from Tanzania indicates that inadequate planning is a cause of teachers being absent during curriculum training [3]. Aydin, Ozfidan, and Carothers [6] reveal that classroom planning presents a challenge for teachers in the United States too. Adequate accounting subject content knowledge is a prerequisite for EMS teaching practice [7]. In Kenya, teaching the content knowledge (that is, the subject that a teacher is expected to teach) poses challenges for teachers in relation to alignment with teachers' subject specialization [8]. Inadequate content knowledge is also a challenge in Ghana [9]. Likewise, schools in the United Kingdom experience challenges related to teachers' inadequate subject content knowledge [4].

The authors of this paper propose using various methodological approaches to help teachers approach lessons differently. However, a study in Kenya shows that initial teacher education programmes do not adequately prepare pre-service teachers, for example, in the area of pedagogical and content knowledge [8], and beginning teachers in that country, like their counterparts, the world over, experience a theory-practice dilemma. Teacher's choice of predominantly theoretical method is also a challenge in Oyo State [2].

In light of the above, the authors concur with Dewey, as cited by Agu [10], that, "If we teach today as we taught yesterday, we rob our children of tomorrow". This statement emphasizes the need to investigate the challenges hindering the PCP of EMS teachers in teaching financial literacy, which was the primary focus of this study. Despite the challenges encountered by teachers and referred to above, early researchers recommend solutions to address the challenges. For instance, in South Africa, the Integrated Quality Management System (IQMS), particularly performance standards 1 to 7 , are used to address challenges faced by teachers [11]. Continuous professional development practice is also used to address the challenges mentioned above [12]. Teachers' professional development is promoted in Nigeria [13]. In the United Kingdom, continuous professional development practice is used to address this limitation [14]. Despite efforts in South Africa to improve subject content knowledge and collaborative teaching by teachers [15], some local EMS teachers still resist teaching in collaboration, or teach a subject they did not specialize in, which results in poor subject content knowledge delivery.

\section{Literature Review}

This section will review literature concerning the inadequate content knowledge of the financial literacy in EMS and ineffective collaboration during financial literacy lessons

\subsection{Inadequate Content Knowledge of the Financial Literacy in EMS}

The success of any PCP depends on the type of university training that teachers have received. Adequate subject content knowledge is a prerequisite for EMS teaching practice [7]. A teacher is an interpreter and transformer of subject content knowledge, and should facilitate learners' learning [16]. However, teachers with inadequate subject content knowledge are ill-equipped to explain and represent accounting subject content precisely [17]. Studies that were conducted in Germany reveal that some teachers do not have adequate accounting subject content knowledge. Literature shows that limited learning and professional development opportunities affect teachers' subject content knowledge [18]. It is worth noting that subject content knowledge alone is not sufficient, because knowledge of teaching methods is also necessary for successful pedagogy. Studies on the African continent (Nigeria) revealed similar challenges, that teachers teach subjects in which they did not specialize [2]. Reflecting on the Nigerian context, Omotayo [13] notes that there is a significant mismatch between training and practice, especially amongst teachers trained abroad and teachers trained at Nigerian institutions. Teacher-training institutions have been criticized for their inability to produce teachers who are properly grounded in pedagogy and content [9]. Inadequate funding of most colleges leads to a decline in the quality of education offered [19]. Teachers need to keep up to date with developments in their subject areas [2].

Several studies established that initial teacher education programs do not adequately prepare pre-service teachers with pedagogical and content knowledge [20, 21, 22]. Teachers with limited subject content knowledge are linked to poor quality education and learner achievement [23]. The authors argue that professional teacher qualifications are not taken into consideration when subject allocation is done in schools. Molise [24] indicates that teachers find themselves teaching subjects that they never studied or specialized in. In the case of financial literacy teaching, teachers have problems, because they are not trained as accounting teachers. Most have never had exposure from any of the three EMS learning areas (financial literacy, economy, and entrepreneurship) comprising EMS during their training [25]. Teachers' insufficient subject content knowledge leads to poor performance by learners in South Africa [26]. If teachers are not confident and sufficiently equipped to teach the accounting sections, they will not succeed in getting learners excited about accounting [16]. Insufficient subject content knowledge may lead to negative attitudes of the 
teachers towards the subject [8]. Research has shown that South African teachers' subject content knowledge, especially financial literacy content, has a bearing on the quality of their delivery of EMS lessons [17, 27].

A study in South Africa showed that PCP organized by the district did cater for some teachers who taught EMS, but did not specialize in EMS [20]. The possibility of producing learners with knowledge and skills needed by the modern market is unlikely if the subject content knowledge delivered by teachers is insufficient. Sufficient subject content knowledge enhances PCP. The National Education Policy Act 27 of 1996, cited by [18], stipulates seven roles of teachers that align with critical pedagogy. First, teachers need to display competency and sound knowledge of the subjects they teach. Sufficient subject content knowledge enables teachers to deliver PCP effectively. Insufficient subject content knowledge makes it difficult for teachers to unpack and deliver the knowledge in a manner that is easy for diverse groups of learners to understand. The second role of teachers is interpreters and designers of learning programs and materials. Delivery of subject content knowledge should not be the responsibility of teachers alone. The district-based official (learning facilitator) should monitor and facilitate the delivery, appropriately, of subject content knowledge to learners. Third, teachers have to be scholars, researchers, and lifelong learners. This can be achieved through on-going personal professional development, study, and research in the field, to broaden professional and educational knowledge. The fourth role of teachers is to engage with the community to develop citizenship and provide pastoral care. A teacher needs to understand cultural and socio-economic status of the school, to understand what measures to implement and align with PCP for the benefit of learners. By doing so, a teacher might be able to meet the demands of the curriculum (CAPS). Teachers would, furthermore, develop supportive relations with parents and other stakeholders in education, based on a critical understanding of community and environmental issues. The fifth role of a teacher is leader, administrator, and manager. Teachers should make decisions in their classrooms, manage classroom activities and execute administrative duties effectively. All should be done democratically and in support of learners and colleagues. The sixth role of teachers is assessors. Through assessment, teachers reflect on the subject content they deliver. It is through assessment that teachers can provide feedback to learners about subject content knowledge. The seventh role of teachers is subject specialists. Teachers are required to be "equipped with basic knowledge, skills, values, principles, methods, and procedures relevant to the subject content. Integration of district-based officials and the SMT equips teachers with various approaches that enhance PCP, to the benefit of learners".

However, Feldman [28] indicates that teachers are usually not prepared to accomplish these roles; even their educational backgrounds and experiences might not assist them to fulfil their duties. The view above is supported by Pereira and Sithole [29] who found that some teachers are still applying traditional methods of teaching, instead of adopting modern methods of guiding and facilitating learners' progress. However, some teachers do use modern teaching methods, as required by the CAPS, such as group discussions and role play, to engage learners' different abilities. From the above discussion, we notice that a common challenge is teachers' insufficient subject content knowledge. Papageorgiou and Carpenter [30] clearly state that teachers struggle to fulfil their seven roles. Therefore, we argue that there is a need to investigate the challenges hindering the professional curriculum practice of EMS teachers in teaching financial literacy.

\subsection{Ineffective Collaboration during Financial Literacy Lessons}

Some teachers seem to be resistant to change, because of lack of involvement in curriculum structuring and find it difficult to meet the demand for curriculum reform. As a result, they are unlikely to embrace social change in practice [3]. It is, therefore, important for teachers to allow a social change in their practice, for the benefit of vulnerable learners. In the next subsection, we reflect on diverse collaboration problems experienced globally in PCP for EMS. A study conducted by Dube [31], found that teaching collaboration was not integrated into school planning, which impacted PCP. The lack of collaboration in school planning gives teachers the power to dominate the curriculum and exclude principles of consciousness, dialogue, giving voice to the voiceless, and accommodation of learners' views. The biggest challenge for teachers' collaboration is the inadequate time allotted and scheduled for formal collaboration [2]. Alvunger [19] reports that teaching teachers to collaborate and practice teamwork was also a major obstacle in terms of PCP in that country. We argue that programs for PCP were designed theoretically, but were inapplicable practically. Resistance to collaboration at some schools denies learners the opportunity to voice their views about PCP, which is against the principles of critical pedagogy [29]. Resistance and fear about practicing collaboration affect the implementation of PCP strategies. Similarly, Rajoo [11] established that schools, generally, do not make any provision for the induction of new teachers. Schools do not provide support through mentoring, joint planning, team teaching, and observations of lessons by experienced teachers [32]. Few schools adopt supportive and collaborative approaches for professional learning of teachers [23]. Teaching by collaboration appears to be a challenge in South Africa too. Since the end of apartheid in South Africa, various reforms have been introduced in the education system [1]. Unfortunately, teachers are unable to meet the high expectations of the reform process as 
expressed in the new curriculum. EMS as a subject requires teachers to work collaboratively, however, the collaboration presents an enormous challenge, because teachers are used to working as individuals [22]. For many teachers who cannot cope with sudden changes to the curriculum, fear of failure is a risk that yields high anxiety and reduced resilience, which results in teacher resistance to change [33]. Lacking the capacity to adapt to changes at the classroom level leads to teachers' high level of anxiety and stress, and fear of the outcomes of education [9, 27]. We argue that resistance to collaboration among teachers hampers PCP in EMS. Some teachers still believe in monopolizing education and in principles of power and domination, which exclude the support, voices, and involvement of co-teachers and learners in PCP. The practices of working in silos and excluding others result in low-quality education and poor PCP. Ineffective collaboration and teacher resistance to change appear to be challenges globally $[6,17,33]$. Although centralized education seems to be effective globally, even in countries where there are continuous curriculum reforms, strategies for improving collaboration and enhancing PCP still need attention. Gudyanga and Jita [12] argue that teachers perceive collaboration as time-consuming. Some teachers believe that collaboration is a good strategy for earning points in IQMS, not necessarily a way to improve PCP. The researchers argue that a common practice in schools across the globe is teachers' resistance to collaboration, which contributes to low-quality education and poor PCP. To strengthen PCP in Grade 9 EMS classes, these realities have to be taken into consideration.

\section{Problem Statement}

This paper sought to investigate the challenges hindering the professional curriculum practice of the economic and management sciences (EMS) in teaching financial literacy. Some economic and management science (EMS) teachers seem to be unable to apply appropriate methodologies to impart EMS content in a learning environment [18]. This has negatively impact on the general performance of EMS learners. This impact is evident in the literature on collaboration among EMS teachers, which reports that, if teachers are not confident and sufficiently equipped to teach the accounting sections, they will not succeed in making learners excited about accounting [16]. Furthermore, insufficient content knowledge evidence of the subject EMS requires teachers to work collaboratively during financial literacy lessons; however, the collaboration presents an enormous challenge, because teachers are used to work as individuals [21]. These drawbacks led us to respond to this research question: What are the challenges hindering the professional curriculum practice of economic and management science teachers in teaching financial literacy.

\section{Method}

This research was qualitative and located within the constructivist paradigm, based on the premise that human beings create multiple meanings in their worlds, which are constructed as a result of interaction with others [21]. A qualitative case study design was used for an in-depth analysis of professional curriculum practice of economic and management sciences (EMS) in teaching financial literacy [34]. This enabled me to investigate the professional curriculum practice of EMS teachers [17] and gain an understanding of how they teach financial literacy as part of accounting.

The school was selected because it was accessible for the researchers. Therefore, the participants were selected purposively based on the experience they had and that they were teaching EMS in the same school. The three participants were profiled as follows:

Thabo (Pseudonym), the HoD, is responsible for planning and managing the work of EMS teachers. The HoD of Tlotlo (Pseudonym) Intermediate School started teaching in Kwa-Zulu Natal in 1997 (Grades 4-7); in 2003 he continued teaching (Grades 8-9) at another school. In 2004 he moved to another school to teach (Grades 4-7), and in 2005 he was appointed at the same post level to teach Grades 4-7. In 2012, he was promoted to HoD (Grades 7-9) where he is still working. He has 20 years' experience in his teaching career.

Mapule (pseudonym) is the senior teacher who started teaching in1984 at the intermediate phase (Grades 7-9). In 1989 she continued teaching at another school, in the primary phase (Grades R-6). In 1990 she returned to teaching intermediate phase (Grade 7-9), and this is where she was still teaching at the time of the study. She has 34 years' experience in her teaching career.

Lefa (pseudonym) is the junior teacher who participated in this study started teaching in 2004 at senior phase (Grades 10-12) as a volunteer teacher. In 2004 he switched to teaching as a temporary teacher at the intermediate phase (Grades 7-9). In 2006 he was appointed in a permanent post for the intermediate phase (Grades 7-9), where he was still working at the time of the study. He has 16 years' experience in his teaching career.

The professional experience of participants ranged from 5 to 25 years in the field of education. This range of experience helped to attain viewpoints from participants with experience from Bantu education, outcome-based education (OBE), revised national curriculum statement RNCS, national curriculum statement NCS and CAPS curriculum education.

Data was collected through face-to-face interviews to gather in-depth information regarding the professional curriculum practice of EMS teachers. The in-depth interviews used to probe the teachers' experiences [18] regarding the challenges of teaching financial literacy lasted approximately 55 minutes, and all were audio 
recorded. Video recordings were used to collect data EMS, especially financial literacy lessons. The advantage of using video to capture lessons [21] enabled us to gain rich information and a wide-ranging picture of what transpired in financial literacy lessons [35]. Video recording allowed for a repeated observation of the same lesson and analysis of lessons in much greater depth than would have been possible with other techniques. Observation of two financial literacy lessons lasting for 30 minutes each was conducted per teacher to observe how they tend to teach financial literacy. The interviews and lesson observations were transcribed verbatim. Lessons were transcribed by watching and listening to the videos (lessons). Thematic data analysis was used to identify, analyze, and report patterns within the transcripts [17]. The ethical clearance (with number: UFS-HSD 2016/1370) was obtained from the University of the Free State and permission to conduct the study was sought and granted by the Free State Department of Basic Education (FSDoBE). Informed consent was also obtained from all participants regarding their participation in the research study. To ensure confidentiality and anonymity, pseudonyms were used in place of the participants' real names, including the school [32].

\subsection{Data Analysis}

The study sought to answer the following research question: What are the professional curriculum practice challenges experienced by economic and management sciences teachers in teaching financial literacy? The responses to this question enabled the researcher to distill several themes for discussion. These themes emanated from subjecting the generated data to the analytical lens proposed by Laws, Harper, and Marcus [36], which involved the following steps:

Step 1: Reading and rereading all the collected data: the data from both the interviews and the questionnaires were read and reread to obtain the views of the participants.

Step 2: Drawing up a preliminary list of themes arising from the data: major issues and themes were identified and arranged according to the two main research questions of the study.

Step 3: Re-reading the data: this compelled the researchers to verify whether identified themes were aligned with the participants' comments, and corresponded to the research questions.

Step 4: Linking the themes to quotations and notes: the themes emerging from the data were linked to various scholarly views.

Step 5: Perusing the categories of themes to interpret them: in interpreting the data, the researchers remained cognizant of the research questions.

Step 6: Designing a tool to assist in discerning patterns in the data, to triangulate these during the data analysis process.
Step 7: Interpreting the data and deriving meaning: this is mainly related to highlighting the research findings and arranging material according to categories premised or guided by the research question.

Data from the in-depth interviews were transcribed and then coded and categorized into various themes regarding the professional curriculum practice challenges experienced by economic and management sciences teachers in teaching financial literacy. To ensure the validity of data, member checking was done and themes were sent back to the participants to verify if the data represented what they identified as challenges EMS teachers experienced in teaching financial literacy [35]. Participants also signed consent forms and were assured that their identities will be protected [33] and that the information they provide would be used only for compiling this research which makes suggestions on how the professional curriculum practice of economic and management sciences teachers in teaching financial literacy can be tackled. Pseudonyms are used to protect the participants' identities [17].

\section{Findings}

\subsection{Inadequate Accounting Cash Journal Subject Content Knowledge}

The success of any PCP depends on the type of university training that teachers received. Adequate subject content knowledge is a prerequisite for EMS teaching practice [24]. A teacher is an interpreter and transformer of subject content knowledge, to facilitate learners' learning [12]. Teachers with inadequate subject content knowledge are ill-equipped to explain and present the subject content of accounting precisely [17]. The data concurs, as reflected in what the principal said:

I agree with the point from your research most of our teachers are teaching without subject content knowledge because of teacher-learner ratio mismatch.

The senior teacher added:

Similar to us, when we arrive at the teaching accounting part, I only see different transactions with lots of money, then sometimes I requested my colleague to help in teaching that part when he is free. I only see many books with many columns, and then I don't know which one is used for what.

The data that were collected show a concern that teachers with inadequate subject content knowledge are faced with the challenge of delivering content of subject to the learners in a confident manner. The problem is exacerbated by some teachers finding themselves teaching subjects in which they did not specialize [2]. Some teachers and HODs are not fully knowledgeable about the 
topic of cash journals. The HoD must develop, control, and moderate teachers' work; however, the HoD also struggles with the topic the teachers struggle with. Workshops organized by the district did help some teachers who teach EMS since they did not specialize in it [9].

The HoD expressed his concern about accounting cash journal subject content knowledge as follows:

The main issue of accounting cash journals it's not only a problem to teachers, even me, I'm still learning part of accounting. CAPS document only gives us which topic to treat, but doesn't show how to treat it. Textbooks are available, but aspects of accounting cash journals are difficult to address, as I'm still learning it. Sometimes when teachers request my help, it is difficult to help them, even I requested a subject advisor for help, and unfortunately, he is always busy to reach.

The teachers and HoD face a common challenge concerning financial literacy subject content knowledge. The lack of specialization shows the need to enhance PCP in Grade 9 EMS for teachers, and even the HoD, so that they do not lack content knowledge, but become involved in the teaching, monitoring, and evaluation of curriculum practice by teachers.

The shortcoming of teaching subject knowledge, and not content knowledge, is that, when work needs to be moderated internally and externally, the moderation report shows curriculum has not been covered as a result of insufficient subject content knowledge. This argument was supported by the junior teacher, who said,

To go to class, I always do, even when I have a problem showing learners examples in treating accounting cash journal. During times of moderation, I don't know what to do, because I'm sure what I have discussed to learners it was an incorrect way or not, and then I started to have a problem submitting work for moderation. Because of some of the aspects, I didn't treat them comprehensively.

Insufficient accounting (financial literacy) subject content knowledge denies teachers a platform to fully use their potential, hence, the need for capacitation of EMS teachers to ensure that they can effectively teach financial literacy.

\subsection{Ineffective Collaboration in Teaching Financial Literacy}

The literature revealed that PCP should eliminate centralization of education, and should, instead, accommodate collaboration [25]. Some teachers seem to resist collaboration with other teachers because they do not receive the necessary support to ensure collaboration possible due to a lack of resources [37]. As a result, they are unlikely to embrace collaboration during lesson preparation and delivery [6]. It is, therefore, important that teachers allow collaboration with peers in their practice, to the benefit of vulnerable learners. The senior teacher involved in this study commended as follows about ineffective collaboration in teaching financial literacy, as an important aspect of EMS teaching. The senior teachers said:

The main problem in this school is that we spend most of the time teaching than after we take learners' books to mark a lot, that's why we struggle to meet as EMS educators because each individual focuses on completing the curriculum.

Even when I had a problem in a certain part that I taught I struggled to meet with my colleague for help, due to being busy.

The Department of Education [7] requires teacher collaboration to be restricted to the time allotted and scheduled for formal collaboration. The ineffective collaborative teaching of financial literacy [31] creates a need to work closely with colleagues both internal and neighbouring schools for improved PCP of EMS teachers when teaching financial literacy. The establishment of the professional learning community (PLC) between schools is thus important to develop a space for professional learning that would expand the teachers' pedagogical and content knowledge repertoires [28]. The HoD commented as follows:

I agree with Senior Teacher because a subject meeting is held once per term, due to a lot of work and even when we held it we have only a few minutes, then teachers are not able to fully discuss issues faced in teaching accounting cash journal.

The HoD's remark shows that the collaboration process is conducted in a way that lacks transparency. Subject meetings that are allocated only a few minutes are unlikely to address teaching problems. In the school involved in this study, no pre- and post-exam meetings took place, which could help teachers to work together to address challenges encountered in the practice of accounting. Although, collaboration meetings would identify teachers' strengths and areas that in need of development. The crucial aspect is that participants should design a strategy to address the challenge.

The concerned junior teacher commented as follows:

Again, we reach the end of the first term, but we haven't been able to conduct subject meetings.

As indicated by the junior teacher's comment, the school year was heading towards the end of the first term without them having held a meeting to reflect on individual subject needs, and this hampers the success of PCP of EMS. Teachers have a continuous need to sit together to share the challenges they face in teaching a certain topic, as a way of combating the challenge and enhancing their knowledge. Letshwene [16] confirms that, 
as a result of a lack of capacity to adapt to the changes at the classroom level, teachers experience high levels of anxiety and stress, and live in fear of the outcomes of education. The curriculum coverage was the problem for one participant, as indicated by the comment of the junior teacher:

What teacher is concerned about is how to finish curriculum, not how rightfully deliver it, hence the need to design strategy to enhance PCP.

What the teacher is concerned about is how to finish the curriculum, not how rightfully deliver it, hence the need to design a strategy to enhance PCP.

The principal seemed to be concerned about ineffective teaching collaboration too:

Teachers are working very hard to reach curriculum expectations, sometimes they are even working during the break, and then they don't get time to meet to address challenges faced in teaching.

When teaching the same subject, they need to meet together to see if they are on the same track.

The principal's standpoint indicates the way things are supposed to be, but teachers' massive workload and the expectation that they supervise learners during the lunch break is a challenge for teachers. The above discussion of data that had been collected confirms the lack of collaboration in teaching EMS accounting. The practice is to work in isolation, rather than to do teamwork.

\section{Discussion of Findings}

The effectiveness of professional curriculum practice (PCP) in the teaching of financial literacy depends on programs being available to support teachers' pedagogical methods of delivering subject content knowledge. Workshops are used to assist teachers to approach their teaching tasks in different ways, to enhance personal growth and professional development [18]. Through the programs, teachers can discuss and share information, correct misconceptions, and adopt good pedagogical practices [15]. Van Wyk [15] notes that teachers learn better when they learn together. Teachers tend to follow and adopt what works during training programs. A delivery of subject content knowledge is strengthened by professional development programs with an evaluation component [30]. Teacher workshops help teachers to share specialized subject content knowledge and "pedagogical content knowledge, to share their expertise and approaches to facilitating students' learning" [13]. By attending subject expert workshops and inviting experts to the classroom, teachers could improve the delivery of subject content, and acquire methodologies for successful practice. Studies confirmed that continuous professional development is used at regional and district levels to provide support to schools and to lead teachers [26, 27, 33]. Teacher development and continuing professional development are regarded as support for teachers [17]. These studies recommend that governments employ an adequate number of qualified subject teachers to teach all the subjects at the secondary education level. However, CAPS provides guidelines on assessment in public schools countrywide. In line with CAPS, subject advisors conduct training workshops to direct teachers, provide manuals, and outline topics (financial literacy) to be covered, and for how long [9]. The financial literacy content workshops are conducted by subject advisors and are opportunities to discuss difficulties experienced with content and to provide support for teacher development after initial CAPS training [20]. Subject advisors play a vital role in the enhancement of pedagogical and subject content knowledge. Most teachers view cluster workshops as effective platforms for teachers to share and exchange information with each other [15]. Cluster workshops provide information on alternative methodologies that could be used by teachers to present multiple topics successfully.

Gudyanga and Jita [37] argue that the shift towards teacher collaboration occurs due to an increased understanding that, as teachers work together, "they will express varied perspectives, reveal different teaching styles and experiences, and stimulate reflection and professional growth". They also note that collaboration allows teachers to come together to improve practice, and, through this effort, to assist novice educators; some veteran teachers also find a renewed interest in their craft, which may have been flagging or on the verge of burnout before the experience. Most schools support professional learning communities, as collaborative settings and as a forum through which teachers can facilitate the exchange of ideas and receive assistance in the formulation of common instructional designs and assessments [16]. Studies confirmed that collaboration is sustained via staff meetings and workshops [4, 6, 22]. School clusters also provide a platform for teachers to meet, share, and even try out new ideas to improve teaching and learning [19]. During cluster activities, empowerment is realized through peer teaching/tutoring or coaching, joint subject panel meetings, sharing of local resources, ideas, information, and problems through study groups [28]. To minimize time costs, contact sessions are held at education advisory centers, where direct contact between teachers and advisors takes place. The advisor liberates teachers to accept different cultures in PCP. Contact sessions open networks for communication between teachers and subject advisors. The contact sessions assist teachers to collaborate and help each other to achieve success with PCP. However, schools do not have their advisors to sustain collaboration. Teacher collaboration in South Africa is supported through staff meetings at the school level and external cluster workshops. In 2013, the 
DoE presented a three-day CAPS workshop to empower EMS teachers [16, 28]. The session was facilitated by subject advisors at different learning centers, with the aim of advisors and teachers helping each other to provide good-quality delivery in the classroom [8]. Teachers, principals, and school management teams understand the purpose of sharing views under CAPS. CAPS training workshop functions as bridges to enhance collaboration between schools and clusters.

\section{Conclusion}

The research revealed that insufficient EMS accounting cash journal subject content knowledge and ineffective collaboration in teaching cash journals hinders PCP in Grade 9 EMS subjects. The study recognized the extent of the work done internationally, on the African continent, in the SADC region, and in South Africa to strengthen the quality of the literature consulted to shape this study. The ineffective nature of and resistance to collaboration by novice and veteran teachers to reform from Bantu education, which had been operationalized during the apartheid era, and power (individual), to CAPS/consciousness (collaboration), was a shortcoming concerning PCP. Secondly, a lack of specialization and pre-service practice was a major cause of insufficient cash journal subject content knowledge. Moreover, some teachers are just teaching EMS subject to increase their period workload and not knowing EMS subject content knowledge, which impacts on learners' performance.

We, therefore, recommend that the school should consider subject specialization when allocating teachers, as this will help them to deliver subject content knowledge and pedagogy practice. Specialization helps teachers to know what to do, and to avoid frustration. Such allocation will help to minimize the risk of skipping over certain topics and will bring confidence into the commerce stream. It is imperative to have school subject meetings and professional learning community workshops where teachers can share their experiences and find help.

A limitation of the study was that it was conducted using only one school in the eastern Free State. The purpose of this paper was to not provide a general outcome but to investigate the challenges hindering the professional curriculum practice of economic and management sciences teachers in teaching financial literacy. Grounded on the above limitation, I recommend that the study be expanded by clustering many schools with similar subject content (financial literacy) knowledge.

\section{Acknowledgments}

We are very grateful to Dr. Molaudi Tshelane for his appropriate and constructive suggestions on this published work.

\section{REFERENCES}

[1] Republic of South Africa Department of Basic Education, "Curriculum and Assessment Policy Statement: Intermediate Phase Department of Basic Education, 2011.

[2] Adeleye O.J., "Pedagogical challenges on the effectiveness of business studies teachers in junior secondary schools, Oyo State”, International Journal of Advanced Academic Research, vol. 3, no. 1, 32-46, 2017.

[3] Kitta, S., "Science Teachers' Perceptions of classroom Assessment in Tanzania: An Exploratory Study”, International Journal of Humanities Social Sciences and Education, vol. 1, no. 12, pp. 51-55, 2014.

[4] Darling-Hammond, L., Flook, L., Cook-Harvey, C., Barron, B., Osher, D., "Implications for the Educational Practice of the Science of Learning and Development”, Applied Developmental Science, vol. 24, pp. 97-140, 2020. https://doi.org/10.1080/10888691.2018.1537791

[5] Badugela, T.M., "Problems facing educators in implementing the national curriculum statement: the case study of Tshifhena Secondary school, Vhembe district, Limpopo Province”, Unpublished Masters Dissertation, University of South Africa, South Africa, 2012.

[6] Aydin, H., Ozfidan, B., Carothers, D, "Meeting the Challenges of Curriculum and Instruction in School Settings in the United States”, Journal of Social Studies Education Research, vol. 8, no. 3, pp. 76-92, (2017).

[7] Republic of South Africa Department of Education, "Professional learning communities: A guideline for South African schools”, Government Printer, 2015.

[8] Jerotich, F., Kurgat, S.J., Kimutai, C.K., “Teacher Preparedness in the Implementation of the Integrated Business Studies Curriculum in Public Secondary Schools in Kenya”, Journal of Education and Practice, vol. 8, no. 14, pp. 105-115, 2017.

[9] Kwarteng, J.T., “Accounting Teachers’ Quality of Use of Pre-Tertiary Accounting Curriculum in Ghana's Secondary Schools”, African Journal of Teacher Education, vol. 7, no. 2, pp. 67-90, 2018. https//doi: 10.21083/ajote.v7i2.4157

[10] Agu, A.O. "Beyond orthodox approaches to education reform: innovative strategies for accelerating education for all in the Republic of South Sudan” In Proceedings of the 2017 WECA Conference on Community Association, 2017.

[11] Rajoo, T., “An Investigation Into the Role of the Head of Department (HoD) as an Instructional Leader in the Leadership and Management of the teaching and Learning of Accounting in Two Secondary Schools in one District in Gauteng”, Unpublished Doctoral Dissertation, University of Witwatersrand, Johannesburg, 2013.

[12] Gudyanga, R., Jita, L.C., “Teachers' Implementation of Laboratory Practicals in the South African Physical Sciences Curriculum”, Issues in Educational Research, vol. 29, no. 3, pp. 715-731 (2019). http://www.iier.org.au/iier29/gudyanga .pdf

[13] Omotayo, B.K., “Teachers' Characteristics and Students' 
Performance Level in senior Secondary School Financial Accounting”, Journal of Empirical Studies, vol. 1, no. 2, pp. 48-53, 2014.

[14] Priestley, M., Philippou, S., "The Curriculum is - or Should be - at the Heart of Educational Practice”, The Curriculum Journal, vol. 30, no. 1, pp. 1-7. 2019 .https://doi.org/10.108 0/09585176.2019.1598611

[15] Van Wyk, M.M., "Exploring Collective Learning Conversation in Economics Education: A Social Change Narrative Inquiry Approach”, Journal of Social Science, vol. 43, no. 1, pp. 71-80, 2015.

[16] Letshwene, M.J., “Improving Grade 10 Accounting Teachers' Competencies in the Ekurhuleni District of the Gauteng Province”, Unpublished Doctoral Dissertation, University of South Africa, Pretoria, 2014.

[17] Ngwenya, J.C., “Accounting Teachers’ Understandings and Practices of Teaching and Assessment in a Context of Curriculum Change”, Alternation, vol. 21, no. 1, pp. 171-189, 2014.

[18] Coetzee, E.M., "The Transition from Grade 9 Economic and Management Sciences (GET-Phase) to Grade 10 Accounting (FET-Phase): An Evaluative Study", Unpublished Doctoral Thesis, University of the Free State, Bloemfontein, 2016.

[19] Alvunger, D., “Teachers’ Curriculum Agency in Teaching a Standards-Based Curriculum”, The Curriculum Journal, vol. 29, no. 4, pp. 479-498, 2018. https://doi.org/10.1080/09585 176.2018.1486721

[20] Modise, A.M., "Pedagogical Content Knowledge Challenges of Accounting Teachers", International Journal of Educational Sciences, vol. 13, no. 3, pp. 291-297, 2016.

[21] Ngwenya, J.C., “Assets Teachers Identify for the Teaching of Accounting Education in a Rural Secondary School in Kwa-Zulu Natal”, Perspectives in Education, vol. 38, no. 1, pp. 72-87, 2020.http://dx.doi.org/10.18820/2519593X/pie.v $38 \mathrm{i} 1.6$

[22] Mkandawire, M.T., Walubita, G., "Feedback Study on Developing Critical Literacy Among Malawian and Zambian Undergraduate University Students using a Freirean Praxis”, Journal of Education and Training Studies, vol. 3, no. 2), 150-158, 2015.

[23] Mukeredzi, T.G., 2016, “The 'Journey to Becoming' Pre Service Teachers' Experiences and Understandings of Rural School Practicum in a South African Context”, Global Education Review, vol. 3, no. 1), pp. 88-107.

[24] Molise, H.V., "Exploring the Content Knowledge of Accounting Teachers in Rural Contexts: A Call for a Decoloniality Approach”, International Journal of Learning, Teaching and Educational Research, vol. 19, no. 8, pp. 447458, 2020. https://doi.org/10.26803/ijlter.19.8.24

[25] Bickford, J.H., “The Curriculum Development of Experienced Teachers who are Inexperienced with History-Based Pedagogy", Journal of Social Studies Education Research, vol. 8, no. 1, pp. 146-192, 2017.
[26] Diseko, R., Modiba, W., “Learners' and Their Teacher's Experiences of an Authentic Online Assessment Test in the Understanding of Basic Accounting Content Knowledge”, International E-Journal of Advances in Education, vol. 2, no. 6, pp. 345-356, 2016.

[27] Umugiraneza, O., Bansilal, S., North, D., "Exploring Teachers' Practices in Teaching Mathematics and Statistics in KwaZulu-Natal Schools, South African Journal of Education, vol. 37, no. 2, pp. 1-13, 2017. https//doi: 10.15700/saje.v37n2a1306

[28] Feldman, J., "Pedagogical Habitus Engagement: Teacher Learning and Adaptation in a Professional Learning Community”, Educational Research for Social Change, vol. 5, no. 2, pp. 65-80, 2016. https://dx.doi.org/10.17159/22214070/2016/v5i2a5

[29] Pereira, L., Sithole, B.M., "Learner-Centered Pedagogy in Accounting: Understanding its Meaning from a Bernsteinian Perspective”, African Educational Research Journal, vol. 8, no. 1, pp. 20-30, 2020. https//doi: 10.30918/AERJ.81.20.002

[30] Papageorgiou, E., Carpenter, R., "Prior Accounting Knowledge of First-Year Students at two South African Universities: Contributing Factor to Academic Performance or Not?”, South African Journal of Higher Education, vol. 33, no. 6, pp. 249-264, 2019. https://dx.doi.org/10.20853/33-63032

[31] Dube, B., "Rural Online Learning in the Context of COVID-19 in South Africa: Evoking an Inclusive Education Approach", Multidisciplinary Journal of Educational Research, vol. 10, no. 2, pp. 135-157, 2020. DOI: $10.4471 /$ remie.2020.5607

[32] Sawatzki, C.M., Sullivan, P.A., “Teachers’ Perceptions of Financial Literacy and the Implications for Professional Learning”, Australian Journal of Teacher Education, vol. 42, no. 5, pp. 51-65, 2017.

[33] John, M.,” Physical Sciences Teaching and Learning in Eastern Cape Rural Schools: Reflections of Pre-Service Teachers", South African Journal of Education, vol. 39, no. 1, pp. S1-S11, 2019. https://doi.org/10.15700/saje.v39ns1a166 0

[34] Creswell, J.W., "Qualitative Inquiry and Research Design: Choosing Among Five Approaches”, 3rd ed. Sage, 2013.

[35] Molise H., Dube, B., "Emergency Online Teaching in Economic and Management Sciences Necessitated by the COVID-19 Pandemic: The Need for Healthy Relations in a Rural Schooling Context”, International Journal of Teaching, Learning and Educational Research, vol. 19, no. 6, pp. 387400, 2020. https://doi.org/10.26803/ijlter.19.6.23

[36] Laws, S., Harper, C., Marcus, R., "Research for Development”, Sage, 2003.

[37] Gudyanga, R., Jita, L.C., "Mapping Physical Sciences Teachers' Concerns Regarding the New Curriculum in South Africa”, Issues in Educational Research, vol. 28, no. 2, pp. 405-421, 2018. http://www.iier.org.au/iier28/gudyanga.pdf 